Final author's version. First published in: Deleuze Studies, 5 (1), 63-72.

Contact the author at: vantuinen@gmail.com

\title{
Michelangelo, Leibniz and the Serpentine Figure
}

Sjoerd van Tuinen, Department of Philosophy, Erasmus University Rotterdam

\begin{abstract}
In his lectures from 1987, Deleuze draws an analogy between Michelangelo's figures and Leibnizian substances by claiming that neither are essences but rather sources of modifications or manners of being. The best way to explore this analogy, I argue, is by focusing on Michelangelo's preference for serpentine shapes. By putting key passages from The Logic of Sensation, The Fold: Leibniz and the Baroque and What is Philosophy? in resonance with the Leibnizian accounts of corporeal aggregates and possible worlds on the one hand and art history on the other, I will try to develop a Deleuzian concept for the typically mannerist ideal of the serpentine figure. Although Deleuze usually prefers to speak in musical terms of refrains and counterpoints by which various blocs of sensation resonate with each other, in the visual arts it is the serpentine figure that renders visible sensory becoming as a rhythmic counter-positioning of possible worlds within a single body without organs.
\end{abstract}

Keywords: Michelangelo, serpentine figure, possible worlds, composition, sensation, mannerism 


\section{Michelangelo and Leibniz}

Leibnizian philosophy, Deleuze argues in his lectures from 1987, gives us the key to a problem in painting, under the form: what is mannerism? He draws an analogy between the figures of Michelangelo and Leibniz's doctrine of substances by claiming that neither are essences but rather sources of modifications or manners of being:

In some way, when one thinks of painting that is called mannerist, Leibniz's entire philosophy is without doubt mannerist par excellence. Already with Michelangelo one finds traces of a first and profound mannerism. A mannered posture of Michelangelo is not an essence. It is rather the source of a modification, the source of a manner of being. (Deleuze 1987)

Similarly, in The Fold: Leibniz and the Baroque, Deleuze argues that monads are not Aristotelian or Cartesian essences but individuations of an inessential and antepredicative world. Since each monad envelops this infinite world according to its unique manner, Leibniz can be said to have introduced mannerism in philosophy: 'Essentialism makes a classic of Descartes, while Leibniz's thought appears to be a profound mannerism. Classicism needs a solid and constant attribute for substance, but mannerism is fluid, and the spontaneity of manners replaces the essentiality of the attribute' (Deleuze 1993: 56).

Surprisingly, however, Michelangelo does not feature in The Fold. The only book in which Deleuze refers to Michelangelo is Francis Bacon: The Logic of Sensation. There he argues that 'it was with Michelangelo, with mannerism, that the Figure or the pictorial fact was born in its pure state' (Deleuze 2004: 161; cf. Deleuze 2006: 182). Both Michelangelo and Bacon can be qualified as mannerist in so far as they escape from classical figuration through the 'extraction or isolation' of the 'figural'. Just as a modern painter must liberate himself from the clichés imposed on the image by visual culture (i.e. photography), mannerism strives to relieve the figure of its representative role and places it in an entirely different, spiritual register of sensation, which Deleuze describes as 'a properly pictorial atheism' (Deleuze 2004: 9; Deleuze and Guattari 1994: 194; cf. 
Ambrose 2009). Moreover, this anti-classical liberation of spirituality implies a typically modernist tendency towards deformation and abstraction and a heavy emphasis on medium specificity or material facticity. ${ }^{1}$ As Deleuze writes of the jarring juxtapositions of bodies in Michelangelo's Doni Tondo (also known as The Holy Family, 1503):

The forms may be figurative, and there may still be narrative relations between the characters - but all these connections disappear in favour of a 'matter of fact' or a properly pictorial (or sculptural) ligature, which no longer tells a story and no longer represents anything but its own movement, and which makes these apparently arbitrary elements coagulate in a single continuous flow. (Deleuze 2004: 160)

Or as he puts it earlier on, 'it is as if the organisms were caught up in a whirling or serpentine movement that gives them a single "body" or unites them in a single "fact," apart from any figurative or narrative connection' (Deleuze 2004: 130-1).

This article combines the aforementioned passages and explores in detail Deleuze's analogy between the Michelangelesque figure and the Leibnizian monad. At the centre of the argument is the reference to the typically mannerist figura serpentinata. Michelangelo held that the secret of beauty lies in the alternation of convex and concave forms, where the radius 'jumps' from inside to outside and vice versa, since in this way the figure becomes capable of rendering visible movement. Deleuze refers to the art historian Luciano Bellosi (Deleuze 2004: 196 n. 13), who argues that the Doni Tondo is Michelangelo's first mannerist painting in so far as it breaks with Leonardo's classicist conception of the unity of composition:

The movement of their inter-connecting arms forms a spiral that has something 'serpentine' about it ... To get this spiral effect, Michelangelo twists the figures and makes their bodies bend in a movement that is difficult and complicated. ... It is this quality of unease, unnaturalness, eccentricity and ambiguity that particularly characterises the Mannerist mentality. (Bellosi 1970: 8-10) 
In addition, for Deleuze the serpentine figure also has a complex philosophical genealogy that can be traced back to the uncoiled serpent of Nietzsche's eternal return and to the ontogenetic, 'sinuous outline (serpentement)' in Ravaisson, Bergson and Merleau-Ponty. However, by taking the Leibnizian subtext in Deleuze and Guattari's account of art as the composition of blocs of sensation in What is Philosophy? as my starting point, I argue that it is first of all through Leibniz's theory of corporeal aggregates that we can grasp the meaning of the serpentine figure as an expression of sensory becoming. This choice is further legitimated by the fact that the mannerist unease or disquiet, as mentioned by Bellosi, lies not only at the core of Michelangelo's work, but, as Deleuze emphasises, also constitutes the dynamic element or background (fond) of Leibnizian philosophy ${ }^{2}$ (Deleuze 1993: 87).

\section{Composition}

In What is Philosophy? Deleuze and Guattari argue that, whereas philosophy puts forward concepts, art makes blocs of affects and percepts stand up on their own. This difference coincides with the duality between form of expression and matter of expression:

Conceptual becoming is heterogeneity grasped in an absolute form; sensory becoming is otherness caught up in a matter of expression. The monument does not actualise the virtual event but incorporates or embodies it: it gives it a body, a life, a universe. ... These universes are neither virtual or actual; they are possibles. (Deleuze and Guattari 1994: 177)

Whereas in A Thousand Plateaus artistic and philosophical creation are still approached similarly, Deleuze says that it was only with The Fold (1988), hence with Leibniz, that he was able to 'see better' what this distinction between concepts and figures amounts to (Deleuze 1995: 137). As he argues in this book, structured around the allegory of a twostorey baroque house, a form of expression is produced in a process of actualisation whereas a material is made expressive in a process of realisation. The two processes are 
irreducible to each other, in so far as actualisation relates to the reality of the virtual, whereas realisation relates to the existence of a possible world or universe, 'the possible as aesthetic category' (Deleuze and Guattari 1994: 177). This distinction can help us to get a better grasp on the relation between sensation and physical bodies.

In terms of Leibniz, the difference between the actualisation of the world in the appetitions and perceptions of individual souls and the realisation of the world in bodily interaction is not a difference between two kinds of substances, but between two ways of distributing the world, between the soul taken as a monad in itself and the body taken as a composite of several monads. A soul is an eternal individual unity whereas matter is a continuously varying multiplicity, an aggregation of aggregations ad infinitum. Since, for Leibniz, 'that what is not truly one being is not truly one being either' (To Arnauld, 30 April 1687, AG 86), it follows that matter or extension does not exist. He thus subscribes to the idealist conviction that the extended world exists only in monadic perception.

However, Leibniz simultaneously says that no soul, except God's, can exist without a body, since the body that belongs to it is precisely what connects it with the rest of the world:

Each distinct simple substance or monad, which makes up the center of a composite substance (an animal, for example) and is the principle of its unity, is surrounded by a mass composed of an infinity of other monads, which constitute the body belonging to this central monad, through whose affections the monad represents the things outside it. ('Principles of Nature and Grace', §3, AG 207)

The external world is made up of what Leibniz calls 'secondary matter'. In terms of the Monadology, secondary matter is an infinitely divisible masse brute, made up of an unformed flux of monads chaotically traversing all kinds of interactions and compositions, its indistinct collectivities corresponding to the variability of the unconscious flux of perception ('disquiet' or 'confused murmuring') that is virtually included in every monad and that is the condition of all perception, action and thought 
('New Essays', Preface, AG 297). If the soul is nonetheless capable of extracting distinct perceptions from this insensible flux, this is because it possesses a mediating body or 'primary matter' capable of selecting and organising disparate individuals into the unity corresponding to its 'point of view'. For Leibniz the soul is the 'foundation' or 'form' of this organic composition, whilst the other monads that participate in it are merely its 'requisites' or 'material'. In fact, matter is present only through the organic body by which extensive phenomena are 'realised' and otherwise remains fully abstract and ideal. Matter does not 'exist', although in it is realised something that Deleuze calls 'presence': 'the pure presence of the body becomes visible at the same time that the eye becomes the destined organ of this presence' (Deleuze 2004: 52). For Leibniz this means that, in order for a phenomenon to be real - or, 'well-founded' - there must correspond to each of the soul's clear and distinct perceptions a fully evolved organ composed of other monads, such that a perfect 'resemblance' between form and content is guaranteed.

In Deleuze's reading, there is an 'almost schizophrenic tension' (Deleuze 1993: 33) between the idealist Leibniz and the realist Leibniz. There is a tension, for example, between the claim that God chose a certain world expressed by the individuals that populate it and the claim that each 'windowless' monad freely draws its perceptions from the folds of its own infinite background. For it implies that, if an actual soul is free to hallucinate about other possible worlds, it must be able to perceive other possible phenomena than those chosen by God which also strive to existence. On the level of actualisation, however, Leibniz is necessitated to exclude the reality of the possible, since it is precisely God's choice in bringing into existence this one actual world expressed in individual essences that guarantees the well-foundedness of the phenomenon. It is only on the level of realisation - where de jure harmony depends on a de facto organic perspective or union of body and soul - that Leibniz allows, either within the organic body or at least open to it, more reality than the soul can express by itself. Here the infinitely divisible continuum of secondary or anorganic flux matter is not restricted by God's choice of the actual world and encompasses multiple possible worlds. Even if the law of pre-established harmony guarantees that the moral order of individual souls and the natural order of composite bodies fuse on a shared plane of composition, the actual 
does not therefore constitute the real, which must itself be realised in 'accidental', intermonadic or inter-essential relations. Hence we see why the bodies in which hallucinations can be realised are not necessarily individual or essential and therefore do not necessarily exist. This is Deleuze's point in relation to the Baroque, the 'paradigm' of which he claims to be mannerist (Deleuze 1993: 34, 36-7, 38):

The essence of the Baroque entails neither falling into nor emerging from illusion but rather realizing something in illusion itself, or of tying it to a spiritual presence that endows its spaces and fragments with a collective unity. ... The Baroque artists know well that hallucination does not feign presence, but that presence is hallucinatory. ${ }^{3}$ (Deleuze 1993: 125)

Since the process of realisation does not bear on the virtual but on the possible, a body of sensation or matter of fact is always potentially a non-individual and abstract 'monument' for the presence of another possible world within the actual world.

\section{The Serpentine Figure}

According to Deleuze, 'including possible worlds in the plane of immanence, even in this very sketchy way, makes expressionism the counterpart of constructionism' (Deleuze 1995: 147; cf. Deleuze and Guattari 1994: 183-4). Following Leibniz's distinction between appetition and perception, he says that a possible world is embodied in a compound of affects and percepts (Deleuze and Guattari 1994: 164). Affects and percepts, however, are not the same as affections or perceptions, because they are not reducible to an individual form or soul whose lived organic experience they are. Already for Leibniz, a body can possess a 'plastic' consistency without being individual, since although organs are the perceptual-affective requirement of the development of the life of the individual monad to which a body belongs, the reverse is not the case. ${ }^{4}$ Other material compositions expressing other, non-subjective and hence monstrous or other-worldly sensations are always possible. Only reasonable monads have a so-called 'substantializing bond (vinculum substantiale)' attached to them by which, like a 'judgment of God', the organic compositions are morally bound to their unchanging 
foundations, whereas bodies belonging to animal souls are subject to the continuous transformations of 'the matter-flow as pure productivity' (Deleuze and Guattari 1987: 454), that is, they can always be developed into different possible worlds or folded into different and potentially mutant animals and thus into new composites of sensation (Leibniz, 'New System', AG 141-2; 'Monadology’ §72, AG 222). Each sensation thus 'exists in its possible universe without the concept necessarily existing in its absolute form' (Deleuze and Guattari 1994: 178). Spinoza's observation is valid for Leibniz as well: we do not yet know what sensations a body is capable of. 'Even when they are nonliving, or rather inorganic, things have a lived experience because they are percepts and affects' (Deleuze and Guattari 1994: 154, translation modified). Hence Deleuze's claims, firstly, that blocs of sensation possess the autonomous and inorganic life of 'nonhuman landscapes' and 'nonhuman becomings' by which 'we become universes' (Deleuze and Guattari 1994: 169), and, secondly, that the model of all art is a sensory becoming-animal, in other words, an animation - or 'animalization' (Deleuze 2004: 46) of matter in non-human and non-individual ways.

If, moreover, perception is no longer necessarily subjective, then neither can it be reduced to an objective state of affairs. Rather, there is the unity of eye and matter in the becoming of the pictorial fact. Sensation refers not only to primary matter or contentmatter, but also to the 'immense agitation' (Deleuze 2004: 137) of the secondary or flux matter of which it is composed and in which it is expressed. The body, detached from the individual soul and dispersed in flux, becomes a 'zone of objective indiscernibility or indeterminability' (Deleuze 2004: 157) and with it the well-founded phenomenon gives way to deformation. Whereas classical representation, as Deleuze says in The Logic of Sensation, 'takes the accident into an optical organization that makes it something well founded (a phenomenon) or a "manifestation" of essence' (Deleuze 2004: 126), the mannered postures of Michelangelo's deformed bodies are not fixed individual forms of content, but deform the very object form of human perception and representation governing over sensation, such that forms become 'accidental forms' (Deleuze 1993: 137) or forms of expression and thus sources of endless modifications or modulations. Hence the singular 'athleticism' of mannerist figures: 'What makes deformation a destiny 
is that the body has a necessary relationship with the material structure: not only does the material structure curl around it, but the body must return to the material structure and dissipate into it' (Deleuze 2004: 18). This deformation is reflected by the expressions of swooning, drunkenness, dizziness and vertigo employed by Leibniz to describe what occurs when accidental and essential aspects get confused. As becomes clear from a passage of his 'New System on Nature' that is particularly dear to Deleuze, this confusion is also exemplary of the mannerist or Baroque unease characteristic of Leibniz's philosophy: 'After I established these things, I thought I was entering the port; but when I began to meditate about the union of soul and body, I felt as if I were thrown again into the open sea' (AG 142). If classicism needs a solid and constant attribute for substance or body belonging to the soul, the fluidity of mannerism that replaces the essentiality of the attribute therefore lies precisely in this indiscernibility between primary and secondary matter or between content matter and flux matter.

Now it is this objective indeterminability which Deleuze refers to both with the Michelangelesque ideal of the figura serpentinata and Artaud's concept of a body without organs - that is, not bodies stripped of organs, but bodies upon which organic figures are distributed in the form of multiplicities (Deleuze and Guattari 1987: 30). Leibniz says that although nature is not an organism and hence not everything is organic, organs are everywhere 'clothed with' or 'enfolded in' ('New System', AG 141-2) the texture of secondary matter, for reason of which 'each part of matter can be thought of as a garden full of plants or as a pond full of fish' ('Monadology', §67, AG 222). It follows that each organ is only a fold away from infinity, caught up in an abstract flux of entwined bodies, each of which already contains the germ of another possible world. Similarly, a serpentine figure such as The Rape of the Sabine Virgins (1574-82) by Giambologna, a student of Michelangelo, renders the pictorial fact in such a way that it constantly escapes from itself and dissipates in multiple becomings.

In the history of art, it was perhaps Michelangelo who made us grasp the existence of such a fact most forcefully. What we call 'fact' is first of all the fact that several forms may actually be included in one and the same Figure, 
indissolubly, caught up in a kind of serpentine, like so many necessary accidents continually mounting on top of one another. ... Certainly there is still an organic representation, but even more profoundly, we witness the revelation of the body beneath the organism, which makes organisms and their elements crack or swell, imposes a spasm on them, and puts them into relation with forces. (Deleuze 2004: $160)^{6}$

Put differently, the serpentine figure folds - in an 'unnatural' way - one bloc of sensation into another, 'folds over folds' (Deleuze 1993: 93), within a single body without organs. In A Thousand Plateaus or What is Philosophy?, Deleuze and Guattari prefer to speak in musical terms of relations of counterpoint by which various blocs of sensation resonate with each other, but their equivalent in the visual arts is the rhythmic contrapposto of material figures in a serpentine composition in which 'universes are linked together or separated on their lines of flight, so that the plane may be single at the same time as universes are irreducibly multiple' (Deleuze and Guattari 1994: 196). For what the serpentine figure renders visible - from the queerly elongated limbs or contrived and unstable spatial relationships in mannerist works of art to the modernist 'shattering of lived perceptions into a sort of cubism' (Deleuze and Guattari 1994: 171) - is sensory becoming as a rhythmic counter-positioning of possible worlds on a single plane of composition or fractal line of infinite inflection.

\section{References}

Ambrose, Darren C. (2009) 'Triptychs, Eternity and the Spirituality of the Body', Deleuze Studies, 3:2, pp. 259-73.

Bellosi, Luciano (1970) Michelangelo: Painting, trans. G. Webb, London: Thames and Hudson.

Clements, Robert J. (1961) Michelangelo's Theory of Art, New York: New York University Press. 
Deleuze, Gilles (1987) Seminar on Leibniz, 7.4.87, available at:

http://www.webdeleuze.com

Deleuze, Gilles (1993) The Fold: Leibniz and the Baroque, trans. Tom Conley, Minneapolis: University of Minnesota Press.

Deleuze, Gilles (1995) Negotiations: 1972-1990, trans. Martin. Joughin, New York: Columbia University Press.

Deleuze, Gilles (2004) Francis Bacon: The Logic of Sensation, trans. D. W. Smith, London and New York: Continuum.

Deleuze, Gilles (2006) Two Regimes of Madness: Texts and Interviews 1975-1995, trans. Ames Hodges and Mike Taormina, New York: Semiotext(e).

Deleuze, Gilles and Guattari, Félix (1987) A Thousand Plateaus, trans. Brian Massumi, Minneapolis: University of Minnesota Press.

Deleuze, Gilles and Guattari, Félix (1994) What is Philosophy?, trans. Hugh Tomlinson and Graham Burchell, London and New York: Verso.

Hammond, Matthew (2010) 'Capacity or Plasticity: So Just What is a Body?', in S. van Tuinen and N. McDonnell, eds., Deleuze and the Fold: A Critical Reader, Basingstoke: Palgrave Macmillan, pp. 225-42.

Leibniz, Gottfried Wilhelm (1875-90) Die philosophischen Schriften, ed. C. J. Gerhardt, Berlin and Hildesheim: Georg Olms. (GP)

Leibniz, Gottfried Wilhelm (1989) Philosophical Essays, ed. and trans. R. Ariew and D. Garber, Indianapolis: Hackett. (AG) 
Tolnay, Charles de (1964) The Art and Thought of Michelangelo, trans. N. Buranelli, New York: Pantheon Books and Toronto: Random House.

Tuinen, Sjoerd van (2009) 'Pris dans une sorte de serpentin. Le concept de maniérisme de Deleuze entre Bacon et le baroque', in P.-L. Chénier, D. Giroux and R. Lemieux, eds., Gilles Deleuze. Nouvelles lectures, nouvelles écritures, Québec: Presses de l’Université Laval, pp. $23-44$.

\section{Notes}

${ }^{1}$ Even if Deleuze never systematically developed a concept of mannerism in the way he did for expressionism and the Baroque, his aesthetics is profoundly mannerist. In 'Deleuze's Concept of Mannerism' (forthcoming) I provide an overview of the main components of Deleuze's concept of mannerism, which includes aesthetic, but also logical, ethical and stylistic aspects.

${ }^{2}$ For Alois Riegl's similar observation with regard to Michelangelo's Medici tombs, see also Vlad Ionescu's contribution to this forum.

${ }^{3}$ For a differentiation of mannerism from the Baroque, see Van Tuinen 2009.

${ }^{4}$ For a more elaborate account of the plasticity of the body in Leibniz, see Hammond 2010.

${ }^{5}$ Here we see how Deleuze's concept of the presence of the possible is also related to a Bergsonian concept of fabulation: 'Bergson analyzes fabulation as a visionary faculty very different from the imagination and that consists in creating gods and giants, "semipersonal powers or effective presences". It is exercised first of all in religions, but it is freely developed in art and literature' (Deleuze and Guattari 1994: 230). Just as Michelangelo relied on the power of his artistic mind to improve nature instead of merely 
imitating it, for example to extract from the 'alpine and living stone' of a Carrara mountain top the colossus that is hermetically confined in it and that will 'outlive its maker' (cited in Clements 1961: 12, 23-8), Deleuze and Guattari argue that 'percepts can be telescopic or microscopic, giving characters and landscapes giant dimensions as if they were swollen by a life that no living perception can attain', such that we may say that 'all fabulation is the fabrication of giants' (Deleuze and Guattari 1994: 171). ${ }^{6}$ Interestingly, art historian Charles de Tolnay, although not mentioned by Deleuze, arrives at a stunningly similar conclusion: 'From Michelangelo's works emerges the fact that he had a profound knowledge of anatomy. But he was not interested in anatomy as a science per se - as was Leonardo. Rather it was for him, as was perspective, an auxiliary science, a means to a fundamental knowledge of the structure of the human body, which the artist wanted to re-create in his works, not by copying this or that model, but by grasping the meaning of the human body in its original beauty and in the rhythmic power of its abundant life. ... Even Michelangelo's "theoretical" studies of the human body are purely plastic. Obviously he was never able to regard the skeleton as a system which could be detached from the whole, when it was a question of representing the living body. Only the unity of the plastic bodily form existed for him, a unity in which the muscles and bones merely indicate the inner powers and tensions of the substance which they shape from within. They are not a hidden structure inside the body; on the contrary, bones and muscles are forces, and need the body's substance in order to manifest themselves. Away from the complexus of the body they have no life. The blood stream flows these superhuman forms, and Michelangelo seizes its rhythm - a truly dynamic conception' (Tolnay 1964: 87). 